\title{
DETERMINATION OF THE STANDARD RESISTOR TEMPERATURE COEFFICIENTS AND THEIR UNCERTAINTIES
}

\section{Penentuan Koefisien Suhu Resistor Standard dan Ketidakpastiannya}

\author{
M. Azzumar ${ }^{1}$, L. Khairiyati ${ }^{1}$, and A. Faisal ${ }^{2}$ \\ ${ }^{1}$ Center for Research and Human Resource Development - National Standardization Agency of Indonesia, \\ Kompleks Puspiptek Gedung 430, Setu, Tangerang Selatan, Banten, Indonesia 15314 \\ 2Directorate of National Measurement Standards for Thermoelectricity and Chemistry - National Standardization \\ Agency of Indonesia, Kompleks Puspiptek Gedung 420, Setu, Tangerang Selatan, Banten, Indonesia 15314 \\ e-mail: azum@bsn.go.id
}

Diterima: 7 Agustus 2019, Direvisi: 14 Oktober 2019, Disetujui: 7 November 2019

\begin{abstract}
SNSU TK-BSN's capability in determining the temperature coefficients of a standard resistor has been improved. The temperature coefficient is one of the important parameter in determining the definition of the standard resistor. Currently, the measurement result has been reported together with the measurement uncertainty. The determination itself is based on a numerical approach of Taylor Series Approximation (TSA) instead of based on a fitting to a certain equation. And by this determination, the uncertainty was calculated. The determination was validated by comparing the measurement result committed by SNSU TK-BSN to that of by the manufacturer. The equation for the temperature coefficient follows the parabolic equation with an alpha coefficient of $-5.30 \times 10-8$ $\Omega / \Omega /{ }^{\circ} \mathrm{C}$ and beta coefficient of $-4.70 \times 10-8 \Omega / \Omega /{ }^{\circ} \mathrm{C}^{2}$, with the respective uncertainties of $2.4 \times 10-8 \Omega / \Omega /{ }^{\circ} \mathrm{C}$ and 1.6x $10-8 \Omega / \Omega /{ }^{\circ} \mathrm{C}^{2}$, respectively. SNSU TK-BSN measurement results in determining the temperature coefficient in agreement with the manufacturer's measurement results show an appropriate value. This correspondence has an equivalent degree of 0.20 for the alpha temperature coefficient and 0.27 for the beta coefficient.
\end{abstract}

Keywords: determination of temperature coefficient, standard resistor, uncertainty evaluation, validation

\begin{abstract}
Abstrak
Kemampuan Laboratorium SNSU TK-BSN dalam menentukan koefisien suhu dari resistor standar telah ditingkatkan. Koefisiens suhu merupakan salah satu parameter penting dalam mendefinisikan nilai standar resistor. Saat ini, hasil pengukuran telah dilaporkan bersama dengan nilai ketidakpastian pengukuran. Penentuan itu sendiri didasarkan pada pendekatan numerik Taylor Series Approximation (TSA), yang berdasarkan fitting untuk persamaan tertentu. Sehingga nilai ketidakpastian dapat dilakukan perhitungan. Penentuan ini divalidasi dengan membandingkan hasil pengukuran yang dilakukan oleh SNSU TK-BSN dengan yang dilakukan oleh pabrikan. Persamaan untuk koefisien suhu mengikuti persamaan parabolik dengan koefisien alpha sebesar of $5,30 \times 10-8 \Omega / \Omega /{ }^{\circ} \mathrm{C}$ dan koefisien beta sebesar $-4,70 \times 10-8 \Omega / \Omega /{ }^{\circ} \mathrm{C}^{2}$, dengan ketidakpastian masing-masing secara berturut-turut adalah $2,4 \times 10-8 \Omega / \Omega /{ }^{\circ} \mathrm{C}$ dan $1,6 \times 10-8 \Omega / \Omega /{ }^{\circ} \mathrm{C}^{2}$. Hasil pengukuran SNSU TK-BSN dalam menentukan koefisien suhu yang sesuai dengan hasil pengukuran pabrikan menunjukkan nilai yang berkesesuaian. Kesesuaian tersebut memiliki derajat ekuivalensi sebesar 0,20 untuk koefisien suhu alpha dan 0,27 untuk koefisien beta.
\end{abstract}

Kata kunci: evaluasi ketidakpastian, penentuan koefisien suhu; resistor standar, validasi

\section{INTRODUCTION}

In previous paper, we had discussed a measurement method performed by the Directorate of National Measurement Standards for Thermoelectricity and Chemistry-National Standardization Agency of Indonesia (SNSU TKBSN) (previously Research Centre for Metrology-Indonesian Institute of Sciences (RCM-LIPI)) in characterizing a standard resistor due to temperature variations in order to determine temperature coefficients with high accuracy and good precision using a direct current comparator (DCC) bridge (Khairiyati, Azzumar dan Faisal, 2015). The determination of the thermal coefficient of resistance for precision resistor has been offered as a special test.

Calibration laboratories in the industry have a similar set of standard resistors and DCCBs as well, and usually, the set of resistors are immersed in temperature-controlled oil baths to avoid temperature fluctuation effects to the resistance (Abe, Oe, Kumagai, Zama and Kaneko, 2018). However these test required prior arrangements and the temporary inclusion 
of various components into the measuring system, thereby increasing both measurement uncertainty and the time required for the calibration (Jones and Elmquist, 2007).

A development has been carried out in determining the temperature coefficients. Currently, the measurement result of the temperature coeficient is reported together with their uncertainties. Determination based on a numerical approach of Taylor Series Approximation (TSA). The TSA approach in determining the temperature coefficients allows some errors when performing the characterization measurements. So that these results need to be validated against a value that is considered correct.

The test resistor used in this experiment was a $1 \Omega$ Fluke $742 A$ Series, where the temperature coefficients of this test resistor are reported by the manufacturer on its calibration certificate. Besides, the temperature coefficients considered to not change over time (Fluke, 1988). So the manufacturer's result may be used as a reference in validating the determination of the unknown standard resistor temperature coefficients.

\section{BASIC THEORY}

\section{Resistor Standard}

Maintenance of electrical resistance standards and calibration services are needed standard resistors. Basically most of the national metrology institutes (NMIs) maintain a set of standard resistors. Those resistors are to be traceable to a primary standard, namely a quantized Hall resistance standard (QHRS). For the resistance values of $1 \Omega$ and $10 \Omega$, wirewound standard resistors immersed in a temperature stabilized oil bath has been traditionally and widely utilized in many laboratories. (Kaneko, Takehiko, Takayuki, Masaya and Matsuo, 2016).

The 742A Series used in this paper is small, light, rugged resistance standards. The standards require no temperature-controlled air or oil bath. The 742A Series are well suited for use as the following: working standards and Portable transfer standards. The 742A Series are constructed of arrays of Fluke wire wound precision hermetically-sealed resistors. No adjustable resistors of any kind are used. Each 742A is built with a temperature coefficient near zero at $23{ }^{\circ} \mathrm{C}$. To further reduce errors caused by temperature changes, the binding posts are constructed of low-thermal emf material. Figure 1 shows a front panel view of the 742A series (Fluke, 1988).

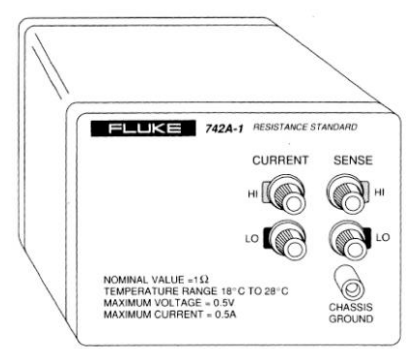

Figure 1 Typical front panel view.

\section{Taylor Series Approximation (TSA)}

A Taylor series approximation (TSA) uses a Taylor series to represent a number as a polynomial that has a very similar value to the number the neighbourhood around. Engineers have long used the Taylor Series Approximation (TSA) as a tool to simplify problems. (Canfield, 1989). The Taylor series is a mathematical tool applied in different areas of engineering including signal processing, control, and voice recognition (Rios, 2017).

\section{Direct Current Comparator Bridge (DCCB)}

The conventional DCC Ratio Bridge error is ranges of $0.1 \mathrm{ppm}$ to $0.05 \mathrm{ppm}$ accuracy level for ratios of $1: 1$ to $10: 1$ (Brown, Wachowicz and Huang, 2016). DCCB is equipment used to measure a value that is known in the form of a ratio of resistance whose value is unknown. The DCCB is built on a transformer with a dual toroidal magnetic core modulator, a magnetic shield that surrounds the modulator core and with multiple winding. The two ratio windings link to the modulator and the magnetic shield which carries the currents to be compared. When the modulator output is zero the current ratio is equal to the turns ratio to a high degree of accuracy (Guildline, 2001). At ampere-turn balance in Equation 1,

$$
\left(N_{X}\right) \times\left(I_{X}\right)=\left(N_{S}\right) \times\left(I_{S}\right)
$$

Where :

$\mathrm{Nx}$ : number of truns in variable comparator winding

Ix : current in the variable comparator winding and $\mathrm{Rx}$

Ns : number of truns in slave fixed comparator winding

Is : lave winding and Rs

In this situation, the second balance condition must be fulfilled, wherein the Ix current flowing through the $N_{x}$ and $R_{x}$ windings have the 
same potential as the Is current flowing through the $N_{s}$ and $R s$ windings $\left(V_{x}=V_{s}\right)$, so that $R_{x}, R_{s}$, $\mathrm{Ix}$, and Is will be interrelated. Mathematically the second balance can be expressed in the following equation:

$I_{X} \cdot R_{X}=I_{S} \cdot R_{S}$

Where :

Ix : current in the variable comparator winding and $\mathrm{Rx}$

$\mathrm{Rx}$ : the resistance as a uknown

Is : current in the slave winding and Rs

Rs : the resistance as a reference

So based on Equation 1 and 2, the relationship between $R_{x}$ and $R_{s}$ can be avowed as a ratio $(\Gamma)$. And $\Gamma$ is the ratio displayed on DCCB when measuring (Azzumar and Faisal, 2015).

\section{METHODS}

\section{Determination of the Temperature Coefficients}

The resistor standard can be modelled as a function of environmental condition, method, and time. The environmental condition may include temperature, humidity, barometric pressure, and power dissipation (Jones, Pritchard \& Elmquist, 2009). All measurements were performed with a direct-current comparator (DCC) bridge and a 1 $\Omega$ calibrated reference resistor in a thermostated oil bath (Callegaro, 2015). Meanwhile, the method consists the used of the DCC Bridge, of the reference standard, and the test resistor. On the other hand, the time is considered as the short term stability along the measurement. The subject of this topic focuses the temperature coefficient, so that the variability of the other input quantities is kept to be constant within a range of uncertainty. The only change remain is the temperature effect. The general characteristic of the resistor to temperature changes may have a relationship as the following Equation 3 (Dudek, Mosiadz, and Orzepowski, 2007).

$$
R_{T}=R_{23} \cdot\left(1+\alpha(T-23)+\beta(T-23)^{2}\right)
$$

Where :

\begin{tabular}{|c|c|}
\hline $\mathrm{RT}_{\mathrm{T}}$ & resistance at temperature $T$ \\
\hline $\mathrm{R}_{23}$ & $\begin{array}{l}\text { resistance at calibration } \\
\text { temperature of } 23^{\circ} \mathrm{C}\end{array}$ \\
\hline T & test temperature \\
\hline$\alpha, \beta$ & $\begin{array}{l}1^{\text {st }} \text { and } 2^{\text {nd }} \text { order tem } \\
\text { coefficient }\end{array}$ \\
\hline
\end{tabular}

A number of 23 is the reference temperature of which it is usually maintained in a laboratory to calibrate the standard resistor. In this experiment, accordance to the labs temperature setup, Fluke $742 \mathrm{~A}$ resistor is builtup with a temperature coefficient near-zero at $23^{\circ} \mathrm{C}$, which means that the turning point from the quadratic equation is at reference temperature that is equal to $23^{\circ} \mathrm{C}$.

On the measurement of a Fluke $742 \mathrm{~A}$ standard resistor to temperature changes, the setup is consists of a DCC bridge, a reference standard resistor, an oil bath for the reference standard resistor and an air bath chamber for the Fluke 742A. And it is depicted as in Figure 2.

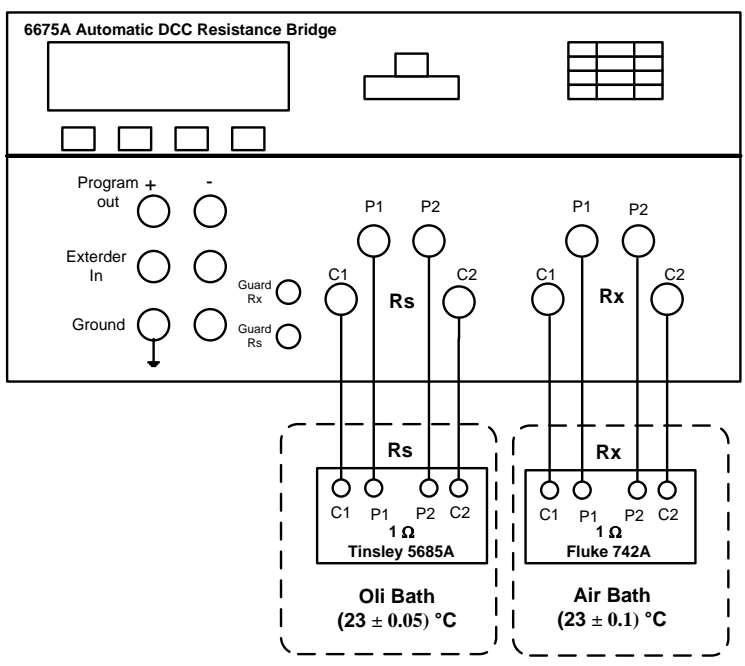

Figure 2 Measurement of a resistor to temperature change configuration.

The temperature of the oil bath is set to $(23 \pm 0.05)^{\circ} \mathrm{C}$. The test temperature of the air bath is varied from $18{ }^{\circ} \mathrm{C}$ to $28^{\circ} \mathrm{C}$ within $\pm 0.1^{\circ} \mathrm{C}$ stability. Meanwhile the ambient room condition is at a temperature of $(23 \pm 2){ }^{\circ} \mathrm{C}$, a relative humidity of $(65 \pm 10) \%$, and a barometric pressure of $(1000 \pm 10) \mathrm{Pa}$. The DCC bridge calculates the unity ratio of one as both at the reference arm and the under test arm measure the same rated current of $(100 \pm 0.02) \mathrm{mA}$. The aforementioned Fluke $742 \mathrm{~A}$ resistor was used as a reference resistor for this measurement, and it was immersed in the temperature-controlled air bath (Domae et all., 2015). Through this setup, the observation of $R_{T}$ is taken as ten repeated measurements for each consecutive temperature changes.

Based on Equation 3, the resistor's characteristic to temperature changes in term of its temperature coefficients can be determined by the second-order Taylor Series Approximation (TSA). The Taylor Series approach is usually used to analyse the differential equation 
(Chaptra, 2010). Considering that the standard resistor is a quadratic function of the temperature, the differential equation up to second order of the Taylor Series for afterwards and beforehand of the midpoint can be written as Equation 4 and Equation 5, respectively.

$$
f\left(x_{i+1}\right)=f\left(x_{i}\right)+f^{\prime}\left(x_{i}\right) \frac{\left(x_{i+1}-x_{i}\right)}{1 !}+f^{\prime \prime}\left(x_{i}\right) \frac{\left(x_{i+1}-x_{i}\right)^{2}}{2 !}
$$

Where :

$f\left(x_{i+1}\right) \quad: \quad x$ function for the temperature variable $\mathrm{i}+1$

$\mathrm{x} \quad$ : $\quad$ temperature at $23^{\circ} \mathrm{C}$

i : value for temperature

$f\left(x_{i-1}\right)=f\left(x_{i}\right)+f^{\prime}\left(x_{i}\right) \frac{\left(x_{i}-x_{i-1}\right)}{1 !}+f^{\prime \prime}\left(x_{i}\right) \frac{\left(x_{i}-x_{i-1}\right)^{2}}{2 !}$

Where :

$f\left(x_{i-1}\right): x$ function for the temperature variable $\mathrm{i}-1$

$\mathrm{x} \quad$ : $\quad$ temperature at $23^{\circ} \mathrm{C}$

i : value for temperature

By subtracting Equation 4 and Equation 5, then it will follow:

$$
f^{\prime}\left(x_{i}\right)=\frac{f\left(x_{i+1}\right)-f\left(x_{i-1}\right)}{\left[\left(x_{i+1}-x_{i}\right)-\left(x_{i-1}-x_{i}\right)\right]}
$$

Where :

$$
\begin{array}{ll}
f^{\prime}\left(x_{i}\right) & : \text { first order differential } \\
\mathrm{x} & : \text { temperature at } 23^{\circ} \mathrm{C} \\
\mathrm{i} & : \text { value for temperature }
\end{array}
$$

And by summing Equation 4 and Equation 5, then it will follow:

$$
f^{\prime \prime}\left(x_{i}\right)=\frac{f\left(x_{i+1}\right)+f\left(x_{i-1}\right)-2 f\left(x_{i}\right)}{\left(\frac{\left(x_{i+1}-x_{i}\right)^{2}+\left(x_{i}-x_{i-1}\right)^{2}}{2 !}\right)}
$$

Where :

$$
\begin{array}{lll}
f^{\prime \prime}\left(x_{i}\right) & : & \text { second order differential } \\
\mathrm{x} & : & \text { temperature at } 23^{\circ} \mathrm{C} \\
\mathrm{i} & : & \text { value for temperature }
\end{array}
$$

By this approximation the temperature coeficients of both alpha $(\alpha)$ and beta $(\beta)$ can be calculated as follows:

$$
\alpha_{i}=\frac{R_{\text {Tref }+i}-R_{\text {Tref }-i}}{\left(\left(T_{\text {ref }}+i\right)-\left(T_{\text {ref }}-i\right)\right) R_{\text {Tref }}}
$$

\section{Where :}

ai : alpha coefficient of temperature to $\mathrm{i}$

$\mathrm{R}_{\text {Tref }}$ : resistance at temperature $\mathrm{T}$ reference
Tref : Temperature reference

i : value for temperature

$$
\beta_{i}=\frac{\left(R_{\text {Tref }+i}+R_{\text {Tref }-i}\right)-2 R_{\text {Tref }}}{\left(\left(\left(T_{\text {ref }}+i\right)-T_{\text {ref }}\right)^{2}+\left(T_{\text {ref }}-\left(T_{\text {ref }}-i\right)\right)^{2}\right) R_{\text {Tref }}}(9)
$$

Where :

$\beta i \quad$ : beta coefficient of temperature to $i$

$\mathrm{R}_{\text {Tref }} \quad$ : resistance at temperature $\mathrm{T}$

reference

Tref : Temperature reference

i : value for temperature

Since the temperature is varied from the midpoint of the temperature reference, $T_{\text {ref }}=$ $23^{\circ} \mathrm{C}$, by the increment of 1 for a range of $18{ }^{\circ} \mathrm{C}$ to $28{ }^{\circ} \mathrm{C}$, The alpha $(\alpha)$ and beta $(\beta)$ are averaged as follows.

$(\alpha, \beta)=\frac{\sum_{i=1}^{5}(\alpha, \beta)_{i}}{5}$

Where :

$\alpha, \beta \quad: \quad 1_{\text {coefficient }}^{\text {st }}$ and $2^{\text {nd }}$ order temperature

\section{Uncertainties of Temperature Coefficients SNSU TK-BSN's evaluation}

The uncertainty evaluation is performed based on JCGM 100: 2008 (BIPM, 2018), by comprising of the 2 types of uncertainty contribution, namely type A and type B. The standard deviation from each averaged alpha $(\alpha)$ and beta $(\beta)$ is considered as a source of type $A$ uncertainty. Meanwhile, type B uncertainties are mainly influenced by a measurement in temperatures and resistances. The uncertainty in term of temperature is regarded as the temperature instability during the measurement at $18{ }^{\circ} \mathrm{C}$ up to $28^{\circ} \mathrm{C}$. On other hand, the uncertainty in term of resistance is regarded to random errors during measurement, the accuracy of the DCC bridge, the DCC bridge resolution in reading, the reference standard resistor calibration value, the reference standard resistor drift, and the temperature instability on the reference standard resistor. As discussed by Dudek (Dudek et al., 2007), the standard uncertainties of both alpha $(\alpha)$ and beta $(\beta)$ can be written as follows:

$u_{B}(\alpha)=\sqrt{\left(\frac{\delta \alpha}{\delta \Delta T}\right)^{2} u^{2}(\Delta T)+\left(\frac{\delta \alpha}{\delta r}\right)^{2} u^{2}(r)}$ 


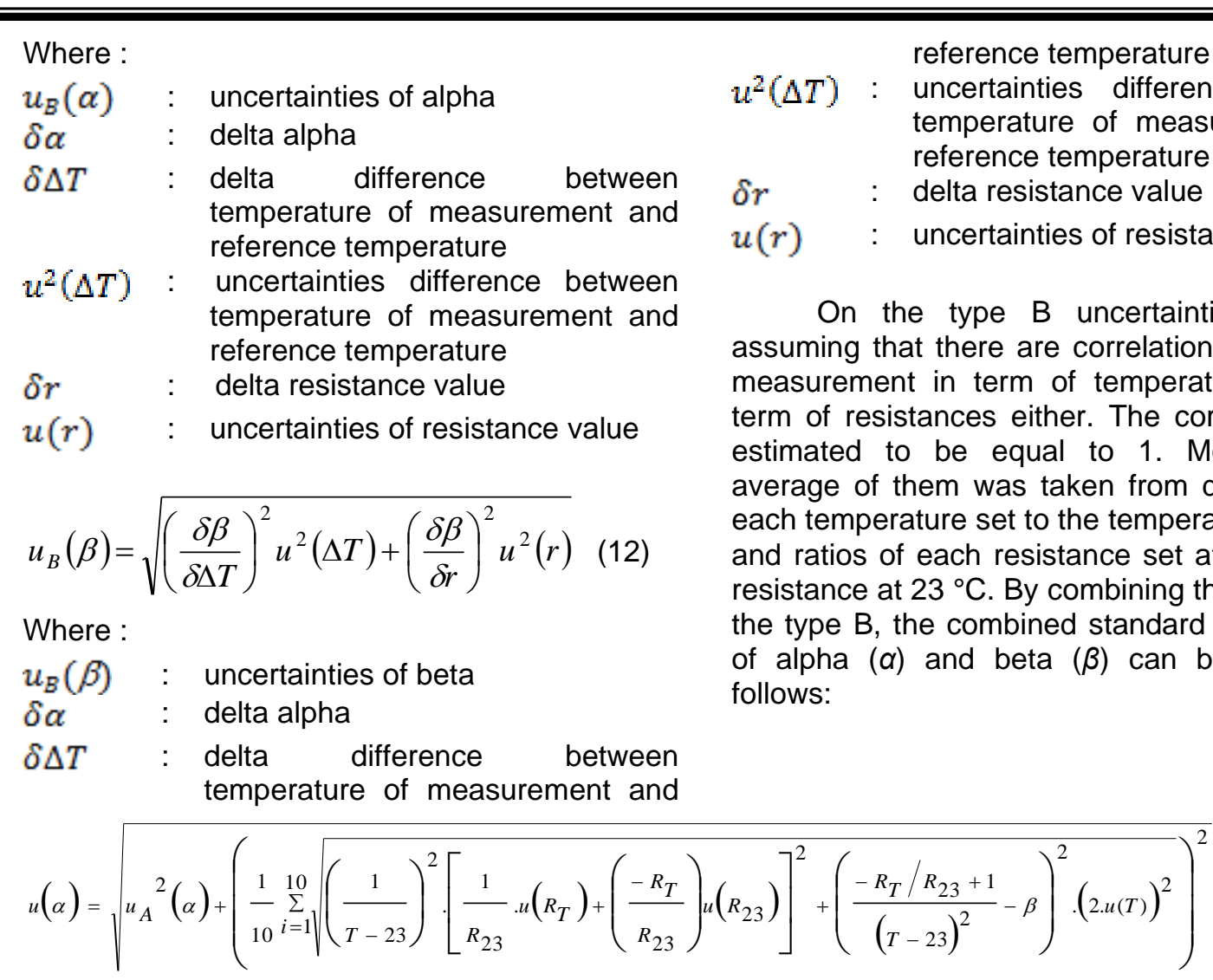

Where:

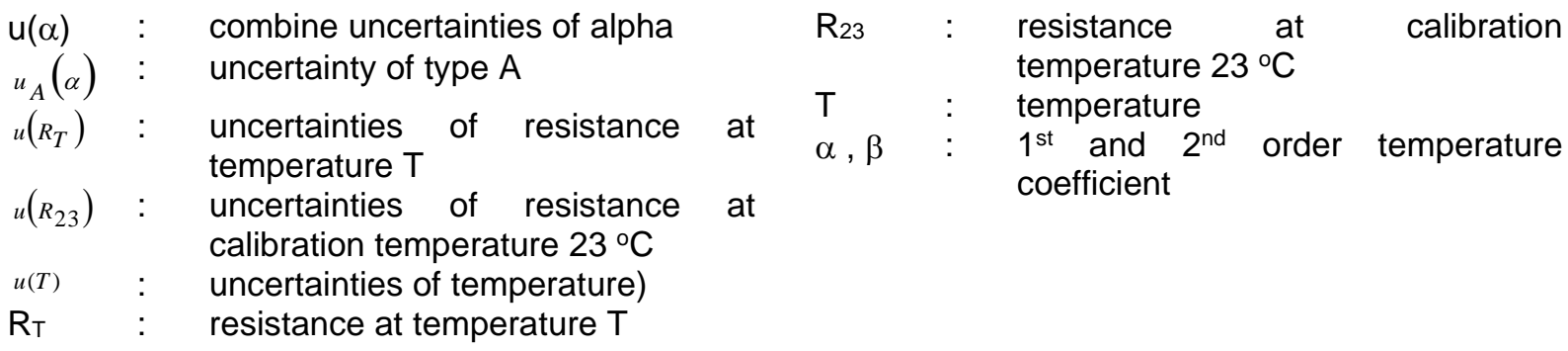

$u(\beta)=\sqrt{u_{A}{ }^{2}(\beta)+\left(\frac{1}{10} \sum_{i=1}^{10} \sqrt{\left(\frac{1}{T-23}\right)^{2} \cdot\left[\frac{1}{R_{23}} \cdot u\left(R_{T}\right)+\left(\frac{-R_{T}}{R_{23}}\right) u\left(R_{23}\right)\right]^{2}+\left[\frac{\alpha}{(T-23)^{2}}-\frac{2\left[R_{T} / R_{23}-1\right]}{(T-23)^{3}}\right]^{2} \cdot(2 \cdot u(T))^{2}}\right)^{2}}$

Where:

$\begin{array}{lll}u(\beta) & : & \text { uncertainties of beta } \\ u_{A}(\beta) & : & \text { uncertainty of type } \mathrm{A} \\ u\left(R_{T}\right) & : & \text { uncertainties of resistance at temperature } \mathrm{T} \\ u\left(R_{23}\right) & : & \text { uncertainties of resistance at calibration temperature } 23^{\circ} \mathrm{C} \\ u(T) & : & \text { uncertainties of temperature }) \\ \mathrm{R}_{\mathrm{T}} & : & \text { resistance at temperature } \mathrm{T} \\ \mathrm{R}_{23} & : \text { resistance at calibration temperature } 23^{\circ} \mathrm{C} \\ \mathrm{T} & : \text { temperature } \\ \alpha, \beta & : & 1^{\text {st }} \text { and } 2^{\text {nd }} \text { order temperature coefficient }\end{array}$




\section{Fluke's evaluation}

A common approach was used by Fluke to determine the temperature coefficients based on a fitting to a typical equation. As it was reported in calibration certificate, the temperature coefficients of both alpha $(\alpha)$ and beta $(\beta)$ were calculated based on fitting coefficients to the quadratic equation of resistance value due to its temperature setting. However, it did not include the uncertainty of the temperature coefficients. To compare the measurement result, it is necessary to calculate the uncertainty of measurement following the measurement result.

Fortunately, Fluke reported sufficient information to evaluate the uncertainties. The calibration certificate reported each resistance value at each temperature settings, consecutively. The type A uncertainty is evaluated based on the standard error of the coefficients of the quadratic equation. The type $B$ uncertainty is evaluated based on a similar approach as ours. The only differences were the uncertainty values in term of temperature and resistance. The combined standard uncertainties of alpha $(\alpha)$ and beta $(\beta)$ can be calculated by using Equation 13 and Equation 14.

\section{RESULTS AND DISCUSSION}

\section{Measurement Result}

The measurement of a tested Fluke 742A standard resistor of $1 \Omega$ in various temperature changes at the range of $18{ }^{\circ} \mathrm{C}$ to $28^{\circ} \mathrm{C}$ was obtained at the condition of that mentioned in chapter above. The measurement result is listed together with the result reported by Fluke in Table 1. Meanwhile, the historical calibration result of the standard resistor calibrated at $23^{\circ} \mathrm{C}$ is tabulated in Table 2.

Table 1 The temperature dependence of the tested standard resistor.

\begin{tabular}{cccc}
\hline $\begin{array}{c}\text { Temp } \\
\left({ }^{\circ} \mathbf{C}\right)\end{array}$ & $\begin{array}{c}\text { RsNSU TK-BSN } \\
(\boldsymbol{\Omega})\end{array}$ & $\begin{array}{c}\text { RFluke }_{(\boldsymbol{\Omega})} \\
18\end{array}$ & $\begin{array}{c}\text { Diff } \\
\left(\times \mathbf{1 0}^{-6}\right)\end{array}$ \\
\hline 19 & 1.0000194 & 1.0000106 & 8.8 \\
20 & 1.0000200 & 1.0000110 & 8.7 \\
21 & 1.0000201 & 1.00000113 & 8.7 \\
22 & 1.0000202 & 1.0000116 & 8.6 \\
23 & 1.0000202 & 1.0000116 & 8.6 \\
24 & 1.0000201 & 1.0000115 & 8.6 \\
25 & 1.0000198 & 1.0000112 & 8.6 \\
26 & 1.0000197 & 1.0000109 & 8.8 \\
27 & 1.0000193 & 1.0000105 & 8.8 \\
28 & 1.0000190 & 1.0000099 & 9.1 \\
\hline
\end{tabular}

Table 2 The calibration result of the tested standard resistor at $23^{\circ} \mathrm{C}$.

\begin{tabular}{ccc}
\hline Date & R & Ref. Lab \\
\hline May 2007 & 1.0000116 & Fluke \\
Feb 2009 & 1.0000146 & SNSU-BSN \\
Apr 2010 & 1.0000157 & SNSU-BSN \\
Jan 2014 & 1.0000188 & SNSU-BSN \\
\hline
\end{tabular}

The temperature dependence of the tested standard resistor was following the similar curve of quadratic equation for both SNSU TK-BSN and Fluke results. The difference was appointed as the self-drift of the standard resistor. Based on Table 2 , the acquired slop was $2.8 \times 10^{-9}$ per day and it was around $8.7 \times 10^{-6} \Omega$ difference from the first calibration date to that of the temperature dependence measurement. From Table 1 it was shown that the difference between SNSU TKBSN and Fluke results was equal to $8.6 \mu \Omega / \Omega$ at $23^{\circ} \mathrm{C}$ in around eight years evaluation.

Furthermore, for more clear visualization of the comparison in temperature dependence, we may see the Figure 3. The "•" symbol represents the measurements of SNSU TK-BSN, and in other hand the " $\diamond$ " symbol represents the measurement of Fluke. The both of the measurements plotted in Figure 3 is the deviation from the based resistance value at the temperature of $23^{\circ} \mathrm{C}$.

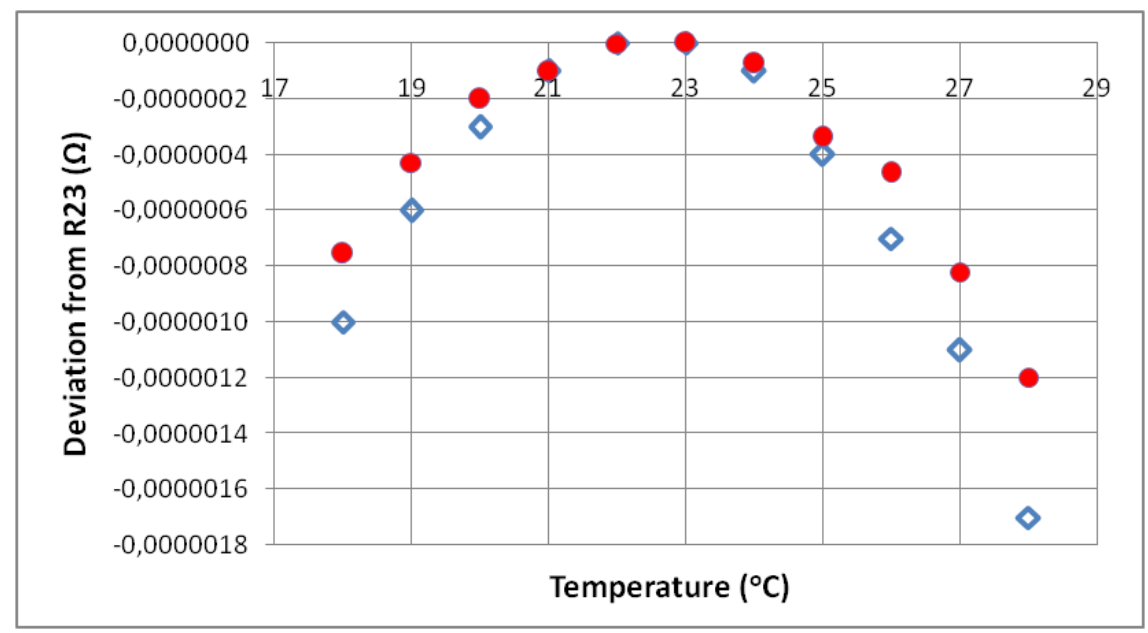

Figure 3 The temperature dependence of the tested standard resistor. 
Based on Equation 8 and Equation 9 can be found the value of temperature coeficients alpha and beta SNSU TK-BSN of alpha coefficient of $-5,30 \times 10-8 \Omega / \Omega /{ }^{\circ} \mathrm{C}$ and beta coefficient of $-4.70 \times 10-8 \Omega / \Omega /{ }^{\circ} \mathrm{C} 2$. The uncertainty for both temperature coefficients are calculated by using Equation 13 and
Equation 14. The uncertainty budget of SNSU TK-BSN measurements for $\alpha$ and $\beta$ can be found in Table 3 and Table 4, respectively. The expanded uncertainties at a confidence level of $95 \%$ with coverage factor of $k=2$, repectively, equal to $2.4 \times 10-8$ and $1.6 \times 10-8$.

Table 3 The SNSU TK-BSN's uncertainty budget of $\alpha$ temperature coefficient.

\begin{tabular}{|c|c|c|}
\hline Quantity & $\begin{array}{l}\text { Probability distribution } \\
\text { /method of evaluation } \\
(\mathrm{A}, \mathrm{B})\end{array}$ & Standard uncertainty \\
\hline$X_{i}$ & & $u\left(X_{i}\right)$ \\
\hline $\begin{array}{l}\text { - Standard error of the mean for } \alpha \\
\text { determination }\end{array}$ & type A & $7.4 \times 10^{-9}$ \\
\hline $\begin{array}{l}\text { - Calibration uncertainty of the test } \\
\text { resistor in each temperature }\end{array}$ & normal/ type B & $2.0 \times 10^{-7}$ \\
\hline - Instability of temperatures & rectangular/ type B & $5.8 \times 10^{-2}$ \\
\hline
\end{tabular}

Table 4 The SNSU TK-BSN's uncertainty budget of $\beta$ temperature coefficient.

\begin{tabular}{|c|c|c|}
\hline Quantity & $\begin{array}{c}\text { Probability distribution /method } \\
\text { of evaluation }(A, B)\end{array}$ & Standard uncertainty \\
\hline $\begin{array}{l}\text { - } X_{i} \\
\text { - Standard error of the mean for } \beta \\
\text { determination } \\
\text { - Calibration uncertainty of the test } \\
\text { resistor in each temperature } \\
\text { - Instability of temperatures }\end{array}$ & $\begin{array}{c}\text { type A } \\
\text { normal/ type B } \\
\text { rectangular/ type B }\end{array}$ & $\begin{array}{c}u\left(X_{i}\right) \\
6.9 \times 10^{-9} \\
2.0 \times 10^{-7} \\
5.8 \times 10^{-2}\end{array}$ \\
\hline
\end{tabular}

In other hand, the temperature coefficients based on data from Fluke calibration certificate are equal to $(-6.9 \pm 7.6) \times$ $10^{-8} \Omega / \Omega /{ }^{\circ} \mathrm{C}$ and $(-5.4 \pm 2.0) \times 10^{-8} \Omega / \Omega /{ }^{\circ} \mathrm{C}^{2}$, respectively for both alpha $(\alpha)$ and beta $(\beta)$. The reported expanded uncertainties are stated at a confidence level of $95 \%$ with coverage factor of $k=2$. And the uncertainty budget of Fluke measurements for $\alpha$ and $\beta$ can be found in Table 5 and Table 6, respectively.

Table 5 The uncertainty budget of $\alpha$ temperature coefficient evaluated from Fluke's calibration certificate.

\begin{tabular}{lcc}
\hline \multicolumn{1}{c}{ Quantity } & $\begin{array}{c}\text { Probability distribution /method } \\
\text { of evaluation (A,B) }\end{array}$ & Standard uncertainty \\
\hline \multicolumn{1}{c}{$X_{i}$} \\
$\begin{array}{l}\text { Standard error of the mean for } \alpha \\
\begin{array}{l}\text { Calibration uncertainty of the test resistor } \\
\text { in each temperature } \\
\text { Instability of temperatures }\end{array}\end{array} \quad$ normal/ type B & $\left.3.8 \times 10^{-8}\right)$ \\
\hline
\end{tabular}

Table 6 The uncertainty budget of $\beta$ temperature coefficient evaluated from Fluke's calibration certificate.

\begin{tabular}{ccc}
\multicolumn{1}{c}{ Quantity } & $\begin{array}{c}\text { Probability distribution /method } \\
\text { of evaluation }(\mathbf{A}, \mathbf{B})\end{array}$ & Standard uncertainty \\
\hline \multicolumn{1}{c}{$X_{i}$} & & $u\left(X_{i}\right)$ \\
- $\begin{array}{l}\text { Standard error of the mean for } \beta \\
\text { determination }\end{array}$ & type A & $8.2 \times 10^{-10}$ \\
$\begin{array}{l}\text { Calibration uncertainty of the test } \\
\text { resistor in each temperature }\end{array}$ & normal/ type B & $4.0 \times 10^{-7}$ \\
- Instability of temperatures & rectangular/ type B & $5.8 \times 10^{-3}$ \\
\hline
\end{tabular}




\section{Validation of Temperature Coefficients Determination}

A calculation was done to validate the temperature coefficients measurements based on SNSU TK-BSN's result to that of Fluke's. The validation was evaluated by using $E_{N}$ number. It represents the degree of equivalency within a combined expanded uncertainty. The equation is written mathematically as follows:

$$
E_{N}=\frac{(\alpha, \beta)_{\text {Fluke }}-(\alpha, \beta)_{S N S U-T K}}{\sqrt{U^{2}\left((\alpha, \beta)_{\text {Fluke }}\right)+U^{2}\left((\alpha, \beta)_{S N S U-T K}\right)}}
$$

Where :

$$
\begin{array}{cl}
E_{N}: \text { En number } \\
\alpha, \beta: 1^{\text {st }} \text { and } 2^{\text {nd }} \text { order temperature } \\
\text { coefficient }
\end{array}
$$

It can be determined that $E_{N}$ for both temperature coeficients of $\alpha$ and $\beta$ are equal to 0.20 and 0.27 . It implies that the measurements has shown a good agreement for $\left|E_{N}\right| \leq 1$.

\section{CONCLUSION}

A development has been carried out in determining the temperature coefficients together with their uncertainties. The determination is evaluated based on a numerical approach of Taylor Series Approximation (TSA). Even though the resistance value at each temperature points differs from its calibration certificate, however, it has been confirmed that it is contributed from the drift of the tested standard resistor. Moreover, the quadratic curve of resistance due to the temperature dependency may be same over time within a certain uncertainty. Either the SNSU TK-BSN measurement method or its evaluation result has shown a good agreement to those from the manufacturer result. that EN for both temperature coeficients of $\alpha$ and $\beta$ are equal to 0.20 and 0.27 .

\section{ACKNOWLEDGEMENT}

The authors would like to express our thanks to the management team at the Directorate of National Measurement Standards for Thermoelectricity and Chemistry-National Standardization Agency of Indonesia (SNSU TK-BSN) (previously Research Centre for Metrology-Indonesian Institute of Sciences (RCM-LIPI)), which supported the research in the form of facilities and infrastructure. We are also indebted to our friends, who helped in ensuring that the study ran smoothly, whether directly or indirectly.

\section{REFERENCES}

Abe,T., Oe,T., Kumagai, M., Zama, M., and N H Kaneko. (2018). Resistors and continuing drift-rate evaluation of $1 \Omega$ and $10 \Omega$ standard resistors. IEEE.

Azzumar, M., \& Faisal, A. (2016). Diseminasi resistor standar $1 \mathrm{k \omega}$ ke standar kerja. Jurnal Standardisasi, 17(3), 223232.

Brown, D, Wachowicz A, and Huang S. (2016). The enhanced performance of the dcc current comparator using accubridge technology. IEEE

Callegaro L, Cassiago C, and Gasparotto E. (2015). Simulated shunts as dc lowresistance travelling standards. IEEE.

Canfield, R, A. (1989). An approximation function for frequency constrained structural optimization. Flight Dynamics Laboratory Air Force Wright Aeronautical Laboratories *Wright-Patterson AFB, Ohio.

Chapra, S.C., and Canale, R.P. (2010). Numerical methods for engineers. mcgraw-hill companies, New York, USA

Domae, A., Abe, T., Kumagai, M., Zama, M., Oe, T., \& Kaneko, N. H. (2015). Development and Evaluation of HighStability Metal-Foil Resistor With a Resistance of $1 \mathrm{k} \Omega$. IEEE Transactions on Instrumentation and Measurement, 64(6), 1490-1495.

Dudek E., Mosiadz M., and Orzepowski M. (2007). Uncertainties of resistors temperature coefficients. Measurement Science Review, 7(3), 23-26.

Fluke. (1988). 742A Series instruction manual. retrieved from http://download.flukecal.com/pub/literatur e/742a_imeng0100.pdf, Accessed on 22 December 2016

Guildline. (2001). Technical manual for model 6675A automatic direct-current comparator resistance bridge.

JCGM 100:2008. (2008). Evaluation of measurement data - guide to the expression of uncertainty in measurement. Retrieved from https://www.bipm.org/utils/common/docu ments/jcgm/JCGM_100_2008_E.pdf, Accessed on 6 September 2018

Jones, G R., and Elmquist R, E.,. (2007). Temperature and pressure coefficients of resistance for Thomas $1 \Omega$ resistor. Technical papers measure. ww.ncsli.org 
Jones, G. R., Pritchard, B. J., \& Elmquist, R. E. (2009). Characteristics of precision $1 \Omega$ standard resistors influencing transport behaviour and the uncertainty of key comparisons. Metrologia, 46(5), 503.

Kaneko, N. B, Takehiko, O, Takayuki, A, Masaya, K and Matsuo, Z. (2016). Development of $1 \Omega$ and $10 \Omega$ metal foil standard resistors. IEEE.
Khairiyati, L., Azzumar, M., and Faisal, A.,. (2015). Peningkatan Kemampuan Metrologi - LIPI. Dalam Menentukan Koefisien Suhu Resistor Standar $1 \Omega$ Berbasis Direct Current Comparator Bridge. PPI-KIM, 41, 204-214

Rios, A d P, Agbossou, $\mathrm{K}$ and A Cardenas. (2017). Taylor series approximation of zip model for on-line estimation of residential loads' parameters. IEEE 
